\title{
Sekretarz o Komisji Podręcznikowej
}

\author{
Thomas Strobel \\ Transnationale Wissenschafts- und \\ Verhandlungskultur. Die Gemeinsame Deutsch- \\ -Polnische Schulbuchkommission 1972-1990 \\ V\&R unipress, Göttingen, 2015, ss. 378.
}

Thomas Strobel od 2005 roku jest pracownikiem Instytutu Georga Eckerta w Brunszwicku oraz sekretarzem naukowym Wspólnej Polsko-Niemieckiej Komisji Podręcznikowej ds. podręczników historii i geografii. Studiował on historię i nauki polityczne na uniwersytetach w Heidelbergu, Krakowie, Berlinie i Lipsku. Recenzowana książka została przygotowana na podstawie doktoratu Strobla obronionego na technicznym uniwersytecie w Brunszwiku (Technische Universität Braunschweig) w 2014 roku.

Już na wstępie należy zaznaczyć, że publikacja jest przygotowana rzetelnie, co wynika z ogromnej pracy wykonanej przez autora na przestrzeni ponad jedenastu lat. Dzięki wykorzystaniu olbrzymiej ilości źródeł poziom książki jest ponadprzeciętny. Swoje badania Thomas Strobel przeprowadził zarówno w archiwach w Niemczech, jak i w Polsce, m.in. w: archiwach ministerstw spraw zagranicznych obu państw (Politisches Archiv des Auswärtigen Amtes oraz Archiwum Ministerstwa Spraw Zagranicznych), Bundesarchiv w Kobencji, Archiwum Akt Nowych w Warszawie, Sekretariat Konferencji Ministra Edukacji (Sekretariat der Kultursministerkonferenz) oraz Archiwum Zakładowe Ministerstwa Edukacji Narodowej. Wykorzystał ponadto archiwa partii i organizacji politycznych: archiwa partii i masowych organizacji NRD (Bundesarchiv Berlin-Lichterfelde/Stiftung Archiv der Parteien und Maßorganisationen der DDR im Bundesarchiv), SPD (Archiv der Sozial Demokratie, Bonn), archiwa służb bezpieczeństwa (Bundesbeauftragte für die Unterlagen des Staatssicherheitsdienst der ehemaligen Deutschen Demokratischen Republik, Instytut Pamięci Narodowej), archiwa naukowe (Archiv der Berlin-Brandenburgischen 
Akademie der Wissenschaft, Archiwum Polskiej Akademi Nauk, Universitätsarchiv Saarbrücken), archiwa instytutów zajmujących się działalnością komisji polsko-zachodnioniemieckiej (archiwa Instytutu Georga Eckerta, archiwa Instytutu Zachodniego, archiwa Polskiego Komitetu ds. UNESCO). Autor pozyskał również dokumenty od kilku członków komisji podręcznikowej (profesorowie Udo Arnold, Jörg K. Hoensch, Władysław Markiewicz, Krzysztof Ruchniewicz, Maria Wawrykowa oraz doktor Carl-August Schroeder). Już samo zestawienie ogromnej bazy źródłowej ukazuje rozmiar pracy wykonanej przez autora.

Należy nadmienić również, że Strobel od dziesięciu lat jest sekretarzem naukowym Komisji Podręcznikowej i mógł bezpośrednio obserwować jej pracę. Chociaż nie pracował w komisji w okresie, który opisuje w swej książce, to jego doświadczenie i znajomość specyfiki działania polsko-niemieckiej komisji podręcznikowej jest nie do przecenienia.

Thomas Strobel przeprowadził ponadto wywiady z niektórymi członkami Prezydium komisji podręcznikowej lub osobami zaangażowanymi w jej pracę (27 osób). Wśród najważniejszych nazwisk można wymienić: profesorów Władysława Markiewicza, Klausa Zernacka, Gerarda Labudę oraz Rudolfa Joachima von Thaddena. Niestety wiele z tych osób już nie żyje, ich świadectwa są dziś dla historyków bezcenne.

Główny zrąb przeprowadzonej w książce analizy oparty jest na teorii historii mówionej (oral history): Thomas Strobel przeprowadził 22 wywiady z polskimi i niemieckimi członkami komisji oraz pięć wywiadów z osobami „odgrywającymi ważną rolę w publicznym dyskursie RFN" (s. 39). Pomimo zastosowania tej metody, książka nie ma uchybień metodologicznych. Prowadząc rozmowy, autor był świadomy ograniczeń wynikających $\mathrm{z}$ badania oral history: pamięć ludzka nigdy nie jest wystarczająco trwała i zawsze jest selektywna. Ta uwaga jest moim zdaniem bardzo ważna, zwłaszcza w odniesieniu do czasów PRL-u. Szczególnie wrażliwe są pytania o to, jaka była rola każdego członka komisji, jakie były ich motywacje oraz przede wszystkim pytania o to, kto był członkiem partii robotniczej czy informatorem/agentem służb bezpieczeństwa.

Kolejna metoda badawcza, która stanowi jedną z podstaw publikacji, opiera się na założeniach socjologii organizacji. Autor bada metody komunikacji w komisji, praktykę pracy oraz kształtujące się zwyczaje.

Głównym pytaniem badawczym postawionym przez Strobla jest: „Jak kultura organizacyjna i społeczne mechanizmy sprzyjały instytucjonalizacji i jak one doprowadziły do stworzenia stabilnej organizacji?” Za tym pytaniem idzie główna hipoteza: „Polsko-niemiecka komisja podręcznikowa rozwijała się w relację komunikacji i aktów, która materializowała się w zalecenia z 1976 roku oraz Prezydium. Komisja była więc miejscem społecznej interakcji, w której dzielono role i wyrażono swoje oczekiwania”.

Praca jest podzielona na cztery główne rozdziały. Rozpoczyna ją czterdziestostronicowy wstęp przedstawiający założenia teoretyczne, metodologiczne, pytania i hipotezy. We wstępie Strobel bardzo precyzyjnie przedstawia stan badań nad polsko-niemiecką komisją podręcznikową oraz omawia najważniejsze publikacje dotyczące tego zagadnienia ${ }^{1}$. $\mathrm{W}$ tym miejscu autor zwrócił również uwagę na rolę tej komisji w badaniu wprowadzania

1 Przykładowo: G. Rhode, Deutsch-Polnische Konferenzen. Hoffnungen, Möglichkeiten, Probleme, „Deutsche Studien” 1974, t. 45, nr 12, s. 127-140 lub W. Markiewicz, M. Wojciechowski, Z prac komisji podręcznikowej Polska-RFN, „Nowe Drogi” 1975, nr 9, s. 132-141. 
zmian do podręczników oraz podkreśla, że komisja była pierwszym przypadkiem dialogu pomiędzy dwoma różnymi systemami politycznymi o różnych podstawach ideologicznych. Pierwszą część pracy zamyka szeroki opis źródeł, archiwów oraz przeprowadzonych wywiadów.

Druga część książki traktuje o historii i kontekstach międzynarodowej rewizji podręczników oraz polsko-niemieckich kontaktach naukowych. Autor opisuje w niej proces tworzenia dialogu i współpracy: wspomina historię przed powołaniem do życia komisji, czyli inicjatywy z lat trzydziestych oraz pięćdziesiątych XX wieku, kiedy Enno Meyer wypracowywał zalecenia z polonijnymi ekspertami i kiedy się zaczęła wymiana badawcza pod auspicjami Deutscher Akademischer Austauschdienst (DAAD). Co ciekawe, daje się zauważyć ciągłość personalną, wielu późniejszych członków komisji skorzystało w tym czasie z możliwości wyjazdu do Niemiec.

Trzeci rozdział koncentruje się na politycznych ramach transnarodowych stosunków naukowych. Strobel bardzo sumiennie opisuje polityczne osadzenie działalności komisji w obu państwach, od ministerstw do komisji UNESCO i każdego instytutu naukowego wspierającego pracę komisji. Autor analizuje historię i rolę każdej instytucji, czyniąc to w sposób przejrzysty i łatwy w odbiorze. Trzeci rozdział zawiera również historię działalności komisji. Według autora, jej historię warto zacząć od lat sześćdziesiątych XX wieku. Był to okres rozpoczynający dialog po orędziu biskupów polskich, ale jeszcze przed utworzeniem Układu Warszawskiego 7 grudnia 1970 roku. Wtedy odbywały się pierwsze seminaria ds. rewizji podręczników w Niemczech, zwłaszcza w ramach Ewangelickiej Akademii w Berlinie. Najważniejszym wydarzeniem w początkowym okresie działalności komisji było spotkanie obu komitetów ds. UNESCO na głównej konferencji w Paryżu w 1965 roku, gdzie zdecydowano o rozpoczęciu dialogu dotyczącego rewizji podręczników pod auspicjami UNESCO. Autor nakreślił kontekst negocjacji, podpisania i (skomplikowanej) ratyfikacji Układu Warszawskiego z 1970 roku oraz jego wpływ na późniejszą pracę komisji podręcznikowej. Co ciekawe, w pierwszych latach pracy tej komisji to właśnie wykonanie pierwotnych zaleceń było największym wyzwaniem. Później nadeszły inne kryzysy, z których największym było wprowadzenie stanu wojennego w Polsce w grudniu 1981 roku. Pomimo tych dramatycznych wydarzeń i niepozbawionych podstaw wątpliwości dotyczących autonomii komisji, po krótkiej przerwie zdecydowano o kontynuacji obrad w 1982 roku. Drugim, choć mniejszym kryzysem w ramach komisji, było odwołanie Władysława Markiewicza z funkcji przewodniczącego komisji w roku 1984.

Czwartą część pracy należy zdecydowanie określić jako najważniejszą, to w niej Thomas Stroblel prezentuje wyniki swoich badań (w szczególności badań socjologicznych). Część ta liczy ponad 120 stroń, podczas gdy np. drugi rozdział ma ich tylko 27. Sprawia to wrażenie, że struktura pracy nie jest do końca przemyślana, i choć jest przejrzysta i czytelna, to brakuje w niej równowagi.

Autor skrupulatnie analizuje procedury nominacji członków oraz szczegóły działalności komisji. Co ciekawe, nie ucieka on od opisu relacji niektórych członków komisji ze Służbą Bezpieczeństwa (SB) (choć przez uprzejmość nie wymienia ich nazwisk). Strobla jako badacza interesuje jedynie zakres autonomii komisji w takim kontekście politycznym. Według standardów służb komunistycznych komisja ta była relatywnie niezależna. 
Nie oznacza to, że nie było w niej agentury SB. Głównym zadaniem służb było monitorowanie działalności profesora Markiewicza w latach osiemdziesiątych. Jednakże praca komisji nie ucierpiała z powodu inwigilacji i była ona w stanie dojść do kompromisu w sprawie opracowania zaleceń oraz organizować konferencje nawet w czasie kryzysu wywołanego wprowadzeniem stanu wojennego ${ }^{2}$.

Następnym przedmiotem analizy są rytuały, symbole komunikacji w działalności komisji. Szczególną uwagę autor zwraca na znaczenie i użycie symbolu parasola UNESCO, pod auspicjami której powstała komisja podręcznikowa. Zajmuje się również symbolami integracji w komisji, np. kiedy jeden członek miał problemy polityczne po wygłoszeniu swojej opinii, inni członkowie reagowali i okazywali mu wsparcie. Strobel zwraca szczególną uwagę na wytworzenie się i powtarzanie rytuałów podczas pracy komisji i organizacji konferencji. Od 1977 roku zazwyczaj miały one miejsce w tygodniu po Zielonych Świątkach, zawsze organizowana była wspólna wycieczka służąca integracji, a obrady odbywały się w języku niemieckim. Jako ciekawostkę należy podać, że profesor Markiewicz zawsze na początku konferencji proponował używanie języka niemieckiego. Spowodowało to, że niemieccy członkowie komisji częściej niż polscy zabierali głos na posiedzeniach komisji. Jednocześnie wybór języka niemieckiego jako języka obrad pozwolił Polakom uzyskać bezpośredni dostęp do niemieckiej prasy i artykułów naukowych, zaś brak znajomości języka polskiego przez stronę niemiecką powodował, że Niemcy musieli opierać się na tłumaczeniach dostarczonych przez Polaków.

Autor świetnie analizuje relacje i sposoby komunikacji między członkami komisji, zwłaszcza profesora Markiewicza z profesorami Georgiem Eckertem i Walterem Mertineitem. Jednakże, moim zdaniem, autor nie do końca wykorzystał potencjał swoich źródeł. Praca prosi się o socjologiczne porównanie relacji między profesorami Antonim Czubińskim i Walterem Mertineitem czy Klausem Zernackiem.

Bardzo ciekawym wątkiem jest sposób rozwiązywania i studzenia potencjalnych konfliktów podczas posiedzeń Prezydium oraz na konferencjach. Strobel zgłębił biografie poszczególnych członków, przeanalizował ich losy oraz doświadczenia w czasie II wojny światowej. Fakt, że dwóch polskich członków komisji było więźniami obozów koncentracyjnych, a część niemieckich członków pochodziła z ziem polskich, nie pozostawał bez znaczenia dla formy kontaktów oraz przebiegu prac komisji.

Ostatnią częścią książki jest podsumowanie. Podobnie jak wcześniejsze rozdziały, jest ono rzetelnie przygotowane i przemyślane. Poza streszczeniem najważniejszych ustaleń z poprzednich części publikacji Strobel opisuje również czynniki ograniczające postępy w pracy komisji. Dodaje kilka uzupełnień dotyczących ograniczeń w pracy komisji. Najważniejszym z nich były tematy tabu: można było rozmawiać o II wojnie światowej, ale z wyłączeniem informacji o zbrodni katyńskiej, o pakcie Ribbentrop-Mołotow czy o Armii Krajowej. Chociaż należy przyznać, że ograniczenia te wynikały głównie z problemów natury politycznej.

2 Trzeba też nadmienić, że SB nie miała aż tak wielkiego wpływu na pracę komisji. Na przykład służbom nie udało się wyrzucić profesor Wawrykowej po pierwszej konferencji podręcznikowej. Jednak odwołanie profesora Markiewicza jako przewodniczącego komisji w roku 1984 było bez wątpienia związane z działaniami SB. 
Narrację książki wieńczą przedstawione przez autora pomysły na uzupełnienie i kontynuację badań oraz komentarz dotyczący prac aktualnej Polsko-Niemieckiej Komisji Podręcznikowej.

Aneksy podobnie jak cała książka są świetnie opracowane. Liczne tabele i zestawienia czytelnie przedstawiają przewodniczących komisji i odbyte konferencje. Bibliografia jest kompletna i bardzo szczegółowa. Autor dokonał w niej podziału na źródła i literaturę naukową. Może jednak bardziej funkcjonalnym rozwiązaniem byłoby podzielić literaturę naukową tematycznie, by ułatwić czytelnikowi poszukiwanie konkretnego zagadnienia.

Jako że francuski to mój język ojczysty pragnę zwrócić uwagę na analogiczne prace dotyczące francusko-niemieckich prób. Szczególnie polecam dzieła: profesor Etienne François ${ }^{3}$; profesor Hélène Miard-Delacroix ${ }^{4}$ i doktor Emmanuel Droit ${ }^{5}$ o podręczniku francusko-niemieckim, oraz pracę doktor Anne Bazin, o relacjach niemiecko-czeskich i niemiecko-polskich 6 .

Podsumowując, poziom przeprowadzonych przez Thomasa Strobla badań jest bardzo wysoki, dlatego trudno mi było znaleźć nawet niewielkie uchybienia. Istnieją jednak obszary badawcze, których szczegółowa analiza może stanowić wartościowe uzupełnienie do wywodów autora. Uważam, że głębsza i dłuższa analiza prac komisji polsko-enerdowskiej byłaby bardzo ciekawa. Sam autor dostrzega taką potrzebę i wspomina o konferencjach z lat 1950 i 1960 oraz o tym, że kilku członków komisji było również zaangażowanych w naukową współpracę z NRD ${ }^{7}$. To prawda, że kontakty na linii Polska-NRD nie były tak liczne, ale fakt, że aż ośmiu członków komisji podręcznikowej uczestniczyło w obydwu procesach dialogu jest bardzo znaczący.

Książka Strobla umożliwia również przeprowadzenie badań komparatystycznych. Można dokonać porównań z pracą innych komisji historyków na świecie. Komisja jako model procesu zbliżenia może się okazać dobrym wzorem do przeprowadzenia badań w innych częściach świata, np. dotyczących relacji pomiędzy Japonią a Koreą Południową.

Moim zdaniem jednym z niewielu uchybień w książce Thomasa Strobla jest brak głębszej analizy osobistych relacji pomiędzy członkami komisji. Sposób pracy komisji podręcznikowej wynikał także z zaufania, dobrej atmosfery pracy, integracji, dobrej woli i wzajemnego szacunku naukowego. Dzięki pracy w komisji wytworzyły się relacje

E. François, Le manuel franco-allemand d'histoire. Une entreprise inédite, „Vingtième Siècle. Revue d'histoire" 2007/2, nr 94, s. 73-86.

4 H. Miard-Delacroix, Une tâche difficile. Le manuel d'histoire franco-allemand, „Documents. Revue des questions allemandes" 2006, nr 3, s. 55-59.

5 E. Droit, Entre histoire croisée et histoire dénationalisée. Le manuel franco-allemand d'histoire, „Histoire de l'éducation” 2007, 114, s.151-162.

6 A. Bazin, La réconciliation à travers l'écriture d'une histoire commune: l'exemple des commissions d'historiens germano-tchèque et germano-polonaise, „Revue d'études comparatives Est-Ouest" 2000, t. 31, nr 1, s. 33-65.

7 S. Guth, Erzwungene Verständigung. Die Kommission der DDR und der Volksrepublik Polen 1956-1990, „Vierteljahrshefte für Zetigeschichte” 2009, nr 57, s.497-542. Można dodać jego późniejszy opublikowany doktorat: Geschichte als Politik. Der deutsch-polnische Historikerdialog im 20. Jahrhundert, De Gruyter, Oldenburg 2015, 525 s.; P.-F. Weber, RFN-NRD-PRL (1950-1972): Normalizacja polsko-niemiecka jako ménage à trois, „Przegląd Zachodni” 2009, nr 4, s. 147-161. Można do tego również dodać jego doktorat: Le Triangle RFA-RDA-Pologne (1961-1975). Guerre froide et normalisation des relations germano-polonaises, L'Harmattan, Paris 2007, $422 \mathrm{~s}$. 
przyjaźni, nie tylko między profesorami, ale także między ich rodzinami. Zgadzam się w zupełności z przedstawioną przez autora propozycją dalszej pracy i pogłębienia badań socjologicznych dotyczących niektórych polskich członków komisji, takich jak profesorowie Władysław Markiewicz czy Gerard Labuda. Osobiście dodałabym do tej listy również profesorów Janusza Tazbira i Mariana Wojciechowskiego oraz członków komisji z młodszego pokolenia.

To prowadzi do mojej trzeciej propozycji kontynuacji badań: Wspólna Komisja Polsko-Niemiecka Podręcznikowa ds. rewizji podręczników historyków i geografów istnieje do dziś. Myślę, że warto przeanalizować symbole, rytuały, procedury pracy i komunikacji po roku 1990, żeby móc dokonać porównania i wykazać ciągłość oraz zmiany w działalności komisji. Choć zachowano niektóre zwyczaje (spotykanie się tydzień po Zielonych Świątkach) to komisja nie obraduje już tak często jak wcześniej. Co więcej, obrady komisji stały się dwujęzyczne, a niektórzy nowi członkowie nie znają języka niemieckiego. Takie czynniki zapewne wpływają na sposób prac komisji i warto zbadać, w jaki sposób warunkują przebieg i rezultaty prac komisji.

Dodatkowo proponuję skupienie się na aktualnych członkach komisji: dzisiaj mają oni inne pochodzenie i doświadczenie, większość z nich urodziła się po II wojnie światowej, wychowywali się w okresie zimnej wojny, a często otrzymali tytuł profesorski po 1989 roku. Dziś komisja straciła jej wyjątkowy charakter miejsca dialogu pomiędzy Wschodem i Zachodem, ale wciąż pracuje i zajmuje się nowymi projektami, np. od 2008 roku wspólnego podręcznika historii. Jest to ciekawy powrót do korzeni komisji: dydaktyki. Efekty oddziaływania tego nowego projektu na skład i działalność komisji jest według mnie bardzo interesującym polem badawczym, podobnie jak nowy kontekst polityczny (projekt wspólnego podręcznika wspierali ministrowie spraw zagranicznych Frank-Walter Steinmeier i Radosław Sikorski w 2008 roku).

Kolejnym interesującym i wartościowym przedmiotem analizy może być koncepcja pojednania. Podczas swoich badań nad komisją podręcznikową zauważyłam ciekawą zależność, tj. przynależność do konkretnego pokolenia członka komisji warunkuje jego postawę wobec pojednania. Starsi członkowie uważają, że pojednanie jest podstawowym zagadnieniem w pracy komisji oraz jej celem. Młodsze pokolenia zaś za najważniejszy cel uważają proces normalizacji. Co więcej, samo rozumienie pojednania również ulegało przekształceniom i zmianom. Jak widać, pojednanie i normalizacja mogą stanowić podstawę kolejnego opracowania dotyczącego Polsko-Niemieckiej Komisji Podręcznikowej.

Uważam, że książka Thomasa Strobla pozostanie przez długie lata głównym punktem odniesienia dotyczącym wspólnej polsko-niemieckiej komisji podręcznikowej. Praca ta jest oryginalna, jej baza źródłowa głęboka, a poziom naukowy bardzo wysoki. Analiza autora otwiera nowe pole badawcze nie tylko dotyczące polsko-niemieckiego kontekstu, ale również pracy podobnych komisji i instytucji na całym świecie. 